\title{
Impact of Cashless Transactions on Purchasing Behavior of Respondents
}

\author{
Manisha Ohlan ${ }^{1}$, Ella Rani $^{1}$ and C.D. Autade ${ }^{2}$ \\ ${ }^{1}$ Department of Extension Education and Communication Management, \\ I. C. College of Home Sciences and College of Agriculture, CCS Haryana Agricultural \\ University, Hisar, Haryana, India \\ ${ }^{2}$ Mahatma Phule Krishi Vidyapeeth, Rahuri, Maharashtra, India
}

*Corresponding author

\section{A B S T R A C T}

\begin{tabular}{|l|}
\hline Ke y w o r d s \\
Cash less, \\
Preference, \\
Duration, Impact, \\
Utilization
\end{tabular}

\section{Introduction}

A system where no physical cash is in circulation is a cashless system. Payments are made through credit and debit cards, bank electronic fund transfers or virtual wallets. India is a country where $90 \%$ of transactions are paid for in cash because cash facilitates making transactions anonymous, helping conceal activities from the government in a way that might help agents avoid laws, regulations and taxes. The failure of demonetisation to make India a less-cash society does not necessarily imply a complete failure of the larger digitization drive. Data suggest that some components of digital 
payments are up after November 2016, although it is not clear if this is merely a continuation of pre-demonetisation trends or an effect wrought by demonetisation. Nor can one conclude, on the basis of the analysis, that demonetisation has failed, although such data as shown have question remain open to contestation and interpretation.

Hernandez et al., (2014) who revealed that the preference of cash was to refrain from overspending and to keep an insight into the volume of spending. Debit card was utilized by majority of respondents, followed by credit card and Immediate Payment Service (IMPS).However, the benefits of this move have now started trickling in with more and more people switching to digital modes of receiving and making payment. India is gradually transitioning from a cash-centric to cashless economy. Digital transactions are traceable, therefore easily taxable, leaving no room for the circulation of black money. The whole country is undergoing the process of modernisation in money transactions, with epayment services gaining unprecedented momentum. A large number of businesses, even street vendors, are now accepting electronic payments, prompting the people to learn to transact the cashless way at a faster pace than ever before. The effect of demonetization was twofold - a large number of Indians, thus far uncompelled to go cashless, suddenly found themselves warming up to the idea of doing digital transactions, whether by debit card or via e-wallet, incrementally trusting the brands of the major players like PayTM or Mobikwik. Secondly, the convenience of e-wallet transactions via mobile phones made the customers and merchants educate themselves, out of necessity, on how the system worked. Today, this has gotten both customers and merchants a lot closer to now trusting a payment bank with a mobile interface, which is right in the wheelhouse for both Airtel and PayTM. The latest World Bank report has mentioned that the demonetisation will not have any longterm adverse effect on the health of Indian Economy. Rather it will prove beneficial with growth of the Indian economy rising to $7.6 \%$ in fiscal year 2018. Liquidity expansion in the banking system post-demonetisation has helped the banks to lower lending rates, which in turn is bound to lift economic activity.

A part of Digital India programme, the concept of cashless economy in India is centred around the vision of transforming the country into a society, which is digitally enabled and empowered by several modes of cashless transactions. Consequently, digital modes like credit/debit cards, mobile wallets, banks pre-paid cards, UPI, AEPS, USSD, Internet banking etc have gained in currency, leading to cashless India in near future. Postdemonetisation, the people have finally started believing in the power of the plastic money in the form of credit card/debit card, and other channels of electronic payment.

Online banking has gained prominence due to unavailability of enough cash in the market. Moreover, E-commerce modes of making payments have also become popular, as most of the people have now started making payments of even Rs 50 through the digital modes. All these developments are considered to be good for the healthy growth of the economy. Present study was planned to explore preference, duration and impact of using cashless payment methods by respondents.

\section{Materials and Methods}

The study was conducted in Hisar district of Haryana state selected purposively in both rural and urban areas. For rural respondents, from Hisar district two villages; Ludas and Shahpur were selected randomly. For urban respondents, two localities; Sector-14 and 
Sector-15 from Hisar city were selected randomly to assess constraints about cash less system of the respondents. A total of 200 respondents which comprised of 100 rural respondents (25 females, 25 males) from each village and 100 urban respondents (25 females, 25 males) from each locality having at least higher secondary education were selected purposively. A well-structured interview schedule was used as a tool to explore the preference, duration and impact for utilizing cash less payment methods as a tool for data collection.

\section{Results and Discussion}

\section{Preference for cash less payment methods} used by respondents in purchasing

In purchasing, respondents preferred to use different cash less payment methods as presented in Table 1 points out that in rural area, majority of respondents $(67 \%)$ preferred to pay cash for purchasing, which was followed by cash and online (33\%) and online $(13 \%)$. However, in urban area, majority of respondents $(71 \%)$ preferred to pay cash for purchasing, followed by cash and online $(29 \%)$ and online $(15 \%)$.

It was observed that, one tenth (10\%)of respondents preferred to purchased items less than Rs.5,000, which was followed by Rs.5,000-Rs.20,000 (2\%). 12 per cent of respondents preferred to purchased items less than Rs.5,000, which was followed by Rs.5,000-Rs.20,000 (3\%).

The similar trend was followed in case of pooled sample mean. The findings are supported by Hernandez et al., 2014 who revealed that the preference of cash was to refrain from overspending and to keep an insight into the volume of spending.

\section{Duration of utilization of cash less payment system by respondents}

Cash less payment system was utilized very frequently, frequently and rarely by the respondents in rural and urban area has been presented in Table 2. It can be seen from the Table that in rural area, majority of respondents utilized debit and credit card frequently which was given first rank, which was followed by respondents who rarely utilized Real Time Gross Settlement System, National Electronic Funds Transfer and Electronic Clearance Service (II ${ }^{\text {nd }}$ rank each) and Unified Payments Service, Unstructured Supplementary Service Data and Immediate Payments Service (III ${ }^{\text {rd }}$ rank) respectively.

Table.1 Preference for cash less payment methods used by respondents in purchasing

\begin{tabular}{|c|c|c|c|c|}
\hline \multirow[t]{2}{*}{ Sr. No. } & \multirow[t]{2}{*}{ Aspects } & Rural & Urban & Total \\
\hline & & $\begin{array}{c}(\%) \\
(n==100)\end{array}$ & $\begin{array}{c}(\%) \\
(n=100)\end{array}$ & $\begin{array}{c}\mathbf{f}(\%) \\
(\mathrm{N}=\mathbf{2 0 0})\end{array}$ \\
\hline A. & \multicolumn{4}{|c|}{ Type of shopping } \\
\hline 1. & Cash & 67.00 & 71.00 & $138(69.00)$ \\
\hline 2. & On-line & 13.00 & 15.00 & $28(14.00)$ \\
\hline 3. & Both (Cash + Online) & 33.00 & 29.00 & $62(31.00)$ \\
\hline B. & \multicolumn{4}{|c|}{ Value of items preferred for purchasing } \\
\hline 1. & Less than Rs. 5,000 & 10.00 & 12.00 & $22(11.00)$ \\
\hline 2. & Rs. 5,000- Rs. 20,000 & 02.00 & 03.00 & $05(02.50)$ \\
\hline 3. & More than Rs. 20,000 & 00.00 & 00.00 & $00(00.00)$ \\
\hline
\end{tabular}

Figures in parentheses indicate percentage 
Table.2 Duration of utilization of cash less payment system by respondents

\begin{tabular}{|c|c|c|c|c|c|c|c|c|c|c|c|c|c|}
\hline \multirow[t]{2}{*}{$\begin{array}{l}\text { Sr. } \\
\text { No. }\end{array}$} & \multirow[t]{2}{*}{ Bankcards } & \multicolumn{5}{|c|}{$\begin{array}{c}\text { Rural } \\
(n=44)\end{array}$} & \multicolumn{5}{|c|}{$\begin{array}{l}\text { Urban } \\
(n=89)\end{array}$} & \multicolumn{2}{|c|}{$\begin{array}{c}\text { Total } \\
(\mathbf{N}=133)\end{array}$} \\
\hline & & $\begin{array}{c}\text { Very } \\
\text { Frequentl } \\
\text { y (3) }\end{array}$ & $\begin{array}{l}\text { Frequentl } \\
\text { y (2) }\end{array}$ & $\begin{array}{c}\text { Rarel } \\
\text { y (1) }\end{array}$ & $\begin{array}{c}\text { Weighte } \\
\text { d Mean } \\
\text { Score }\end{array}$ & $\begin{array}{c}\text { Ran } \\
\mathbf{k}\end{array}$ & $\begin{array}{c}\text { Very } \\
\text { Frequentl } \\
\text { y (3) }\end{array}$ & $\begin{array}{c}\text { Frequentl } \\
\text { y (2) }\end{array}$ & $\begin{array}{c}\text { Rarel } \\
\text { y (1) }\end{array}$ & $\begin{array}{c}\text { Weighte } \\
\text { d Mean } \\
\text { Score }\end{array}$ & $\begin{array}{c}\operatorname{Ran} \\
\mathbf{k}\end{array}$ & $\begin{array}{c}\text { Weighte } \\
\text { d Mean } \\
\text { Score }\end{array}$ & $\begin{array}{c}\text { Ran } \\
\mathbf{k}\end{array}$ \\
\hline i. & Debit Card & 03 & 19 & 22 & 1.568 & I & 20 & 61 & 08 & 2.134 & I & 0.027 & I \\
\hline ii. & Credit Card & 03 & 19 & 22 & 1.568 & I & 10 & 51 & 28 & 1.797 & II & 0.025 & II \\
\hline iii. & $\begin{array}{l}\text { Real Time } \\
\text { Gross } \\
\text { Settlement } \\
\text { (RTGS) }\end{array}$ & 02 & 00 & 42 & 1.090 & II & 00 & 07 & 82 & 1.078 & VII & 0.016 & V \\
\hline iv. & $\begin{array}{c}\text { National } \\
\text { Electronic } \\
\text { Fund Transfer } \\
(\text { NEFT })\end{array}$ & 02 & 00 & 42 & 1.090 & II & 00 & 07 & 82 & 1.078 & VII & 0.016 & $\mathrm{~V}$ \\
\hline v. & $\begin{array}{c}\text { Electronic } \\
\text { Clearance } \\
\text { Service (ECS) }\end{array}$ & 02 & 00 & 42 & 1.090 & II & 08 & 07 & 74 & 1.258 & IV & 0.017 & IV \\
\hline vi. & $\begin{array}{l}\text { Unified } \\
\text { Payments } \\
\text { Interface } \\
\text { (UPI) }\end{array}$ & 01 & 00 & 43 & 1.045 & III & 06 & 08 & 75 & 1.224 & V & 0.017 & IV \\
\hline vii. & $\begin{array}{c}\text { Unstructured } \\
\text { Supplementar } \\
\text { y Service Data } \\
\text { (USSD) }\end{array}$ & 02 & 00 & 42 & 1.090 & III & 05 & 04 & 80 & 1.157 & VI & 0.016 & V \\
\hline $\begin{array}{c}\text { viii } \\
\text {. }\end{array}$ & $\begin{array}{l}\text { Immediate } \\
\text { Payment } \\
\text { Service } \\
\text { (IMPS) }\end{array}$ & 02 & 00 & 42 & 1.090 & III & 08 & 14 & 67 & 1.337 & III & 0.018 & III \\
\hline
\end{tabular}


Table.3 Utilization of bankcards before demonetization by respondents

\begin{tabular}{|c|c|c|c|c|}
\hline \multirow{2}{*}{ Sr. No. } & Aspects & Rural & Urban & Total \\
\cline { 3 - 5 } & & $\begin{array}{c}\text { \% } \\
(\mathbf{n = 1 0 0})\end{array}$ & $\begin{array}{c}\text { \% } \\
(\mathbf{n = 1 0 0})\end{array}$ & $\begin{array}{c}\mathbf{f}(\mathbf{\%}) \\
(\mathbf{N = 2 0 0})\end{array}$ \\
\hline 1. & Used & 44.00 & 89.00 & $133(66.50)$ \\
\hline 2. & Not Used & 56.00 & 11.00 & $67(33.50)$ \\
\hline
\end{tabular}

Figures in parentheses indicate percentage

Table.4 Impact of cashless transactions on purchasing behaviour of respondents

\begin{tabular}{|c|c|c|c|c|}
\hline \multirow[t]{2}{*}{ Sr. No. } & \multirow{2}{*}{$\begin{array}{l}\text { Locality } \\
\text { Aspects }\end{array}$} & Rural & Urban & Total \\
\hline & & $\begin{array}{c}(\%) \\
(n=100)\end{array}$ & $\begin{array}{c}(\%) \\
(n=100)\end{array}$ & $\begin{array}{c}\mathbf{f}(\%) \\
(\mathrm{N}=\mathbf{2 0 0})\end{array}$ \\
\hline 1. & Increased & 14.00 & 44.00 & $58(29.00)$ \\
\hline 2. & Same & 86.00 & 53.00 & $139(69.50)$ \\
\hline 3. & Decrease & 00.00 & 03.00 & $03(01.50)$ \\
\hline
\end{tabular}

Figures in parentheses indicate percentage

Fig.1 Utilization of bankcards before demonetization by respondents

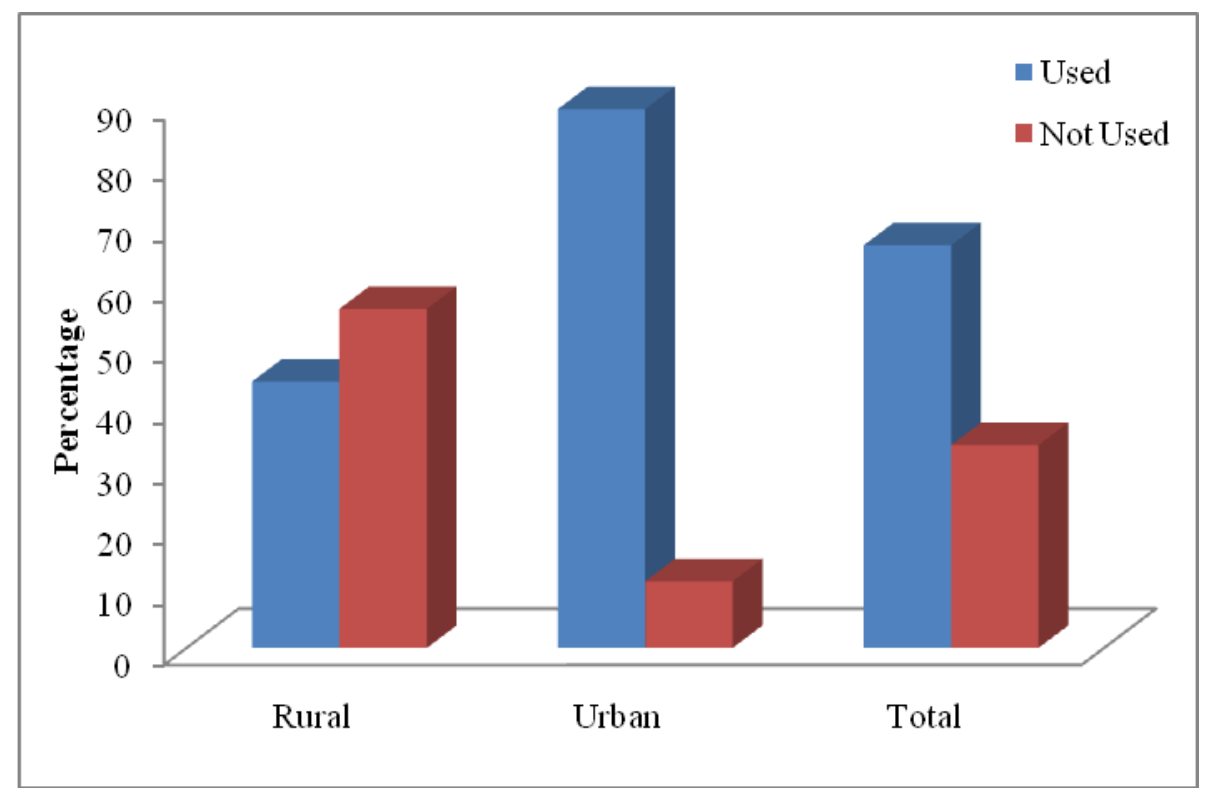


Fig.2 Impact of cashless transactions on purchasing behavior of respondents

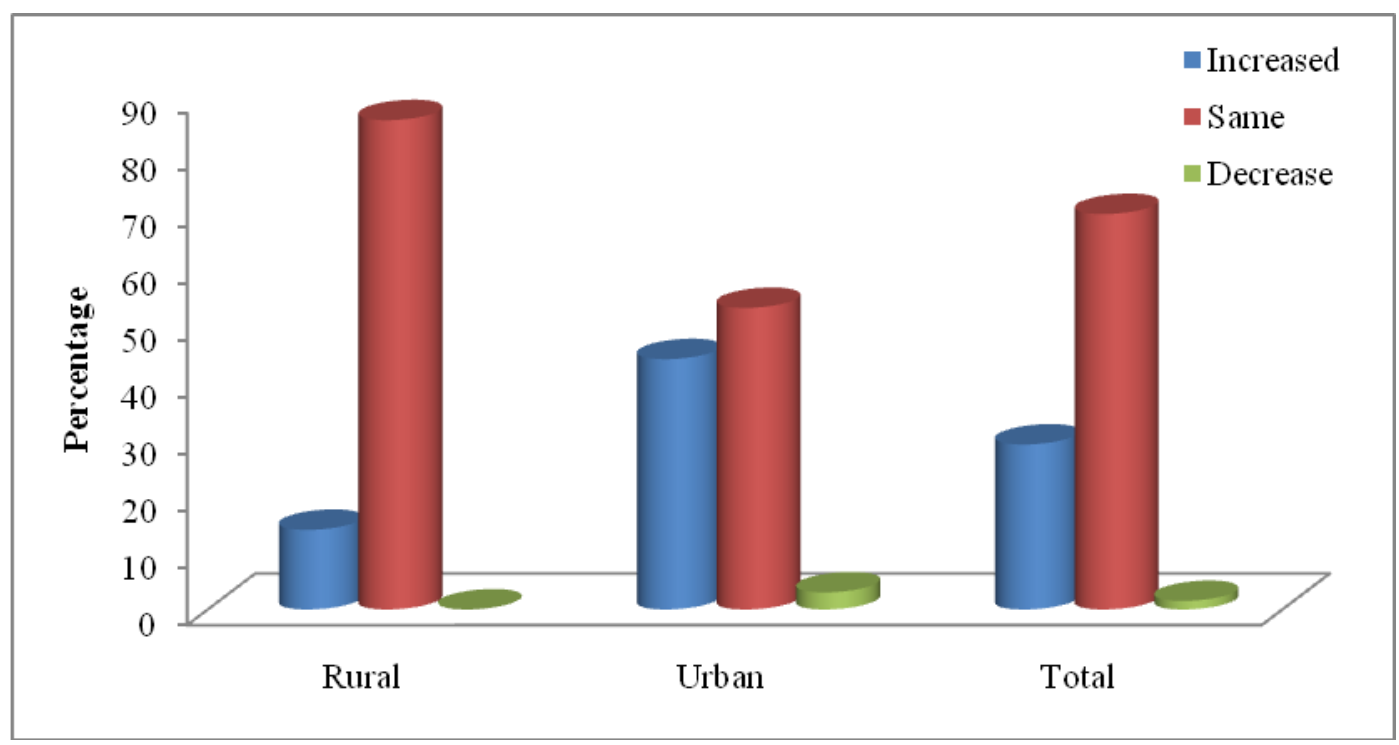

However, in urban area, majority of respondents utilized debit card frequently which was given first rank, which was followed by credit card (II ${ }^{\text {nd }}$ rank), Immediate Payments Service (III ${ }^{\text {rd }}$ rank), Electronic Clearance Service (IV ${ }^{\text {th }}$ rank), Unified Payments Service ( $\mathrm{V}^{\text {th }}$ rank), Unstructured Supplementary Service Data (VI ${ }^{\text {th }}$ rank) and National Electronic Funds Transfer and Electronic Clearance Service (VII ${ }^{\text {th }}$ rank).

It is evident from Table 3 that in aggregated, debit card was utilized by majority of respondents which was given first rank, followed by credit card (II ${ }^{\text {nd }}$ rank), Immediate Payment Service (III ${ }^{\text {rd }}$ rank), Electronic Clearance Service and Unified Payments Service $\left(I^{\text {th }}\right.$ rank each), Real Time Gross Settlement System, National Electronic Funds Transfer and Unstructured Supplementary Service Data $\left(\mathrm{V}^{\text {th }}\right.$ rank each) respectively.

Thus, it can be concluded that debit card was utilized by majority of respondents, followed by credit card and Immediate Payment Service (IMPS).
Utilization of bankcards before demonetization by respondents

Utilization of bankcards by the respondents towards these aspects in both rural and urban area has been presented in Table 3 .

It can be concluded from the Table that 44 per cent and 89 per cent in rural and urban area utilized bankcards before demonetization. While, 56 per cent and 11 per cent of the respondents in rural and urban area did not utilize bankcards before demonetization. In case of pooled sample mean, majority of respondents $(66.5 \%)$ utilized and 33.5 per cent of the respondents did not utilize bankcards before demonetization (Fig. 1).

\section{Impact of cashless transactions on purchasing behavior of respondents}

On the basis of three aspects, impact was noticed in both rural and urban area in Table 4 points out that in rural area, majority of respondents $(86 \%)$ no change on purchasing behaviour, which was followed by respondents whose purchasing behavior 
increased (14\%). However, in urban area, majority of respondents $(53 \%)$ reported that their purchasing behavior remains same, which was followed by respondents whose purchasing behavior increased (44\%) and decreased $(3 \%)$. Thus, in case of pooled sample mean, same trend was followed. The findings are in line of the study of Arabzadeh and Aghaeian (2015), Hirsehman (1979) argued that use of credit cards affected lifestyles, purchasing behaviour and attitude towards debt of the cardholders focused on the influence of method of payment on purchasing behaviour. It was found that individuals who possess both credit bankcards and in store cards were more likely to buy than those who own only bankcards or in-store cards. Further, it was also found that cardholders were more likely to make bigger purchases than non-card holders and mentioned that credit cards facilitate and induce purchases as compared to cash (Fig. 2).

It may be concluded that majority of respondents preferred to use cash in purchasing of items less than Rs.5, 000. None of the respondents preferred cash for purchasing more than Rs. 20,000. Debit card was utilized by majority of respondents, followed by credit card and Immediate Payment Service (IMPS). Majority of respondents in urban area utilized and respondents in rural area did not utilize bankcards before demonetization and no change was observed on their purchasing behaviour.

\section{References}

Arabzadeh, E. and Aghaeian, S. 2015. The relationship of usages and management of credit cards on lifestyles and purchasing behaviours of cardholders. International Journal of Management Research and Business Strategy, 4(3), 12-15.

Hernandez. L., Jonker, N., and Kosse, A. 2014. Cash versus debit card: The role of budget control. The Journal of Consumer Affairs, 51(1): 91-112.

Hirsehman, E. C. 1979. Differences in consumer purchase behaviour by credit card payment system. Journal of Consumer Research, 6 (55): 58-66.

\section{How to cite this article:}

Manisha Ohlan, Ella Rani and Autade, C.D. 2019. Impact of Cashless Transactions on Purchasing Behavior of Respondents. Int.J.Curr.Microbiol.App.Sci. 8(11): 823-829. doi: https://doi.org/10.20546/ijcmas.2019.811.097 